\title{
Problem migracji w filozofii politycznej libertarianizmu
}

DOI 10.35757/CIV.2016.19.05

\section{Wprowadzenie}

Celem niniejszego artykułu jest rekonstrukcja teoretyczna problemu migracji z punktu widzenia libertariańskiego jusnaturalizmu, czyli teorii naturalnych praw podmiotowych. Głównym problemem badawczym artykułu sa następujące pytania: 1. Dlaczego teoria sprawiedliwości libertariańskiego jusnaturalizmu nie może uzasadniać istnienia uprawnienia do migracji? 2. Jaka regułę praktyczna decydowania o przyjmowaniu imigrantów w przestrzeni publicznej można wywieść $z$ teorii sprawiedliwości libertariańskiego jusnaturalizmu? Tezami postawionymi w niniejszym artykule sa zaś następujące twierdzenia: 1 . Teoria sprawiedliwości libertariańskiego jusnaturalizmu nie może uzasadniać uprawnienia do migracji, ponieważ uprawnienie to jest sprzeczne $z$ systemem naturalnych praw własności prywatnej. 2. Reguła praktyczna rządzaca procesem decyzyjnym w sprawie przyjmowania imigrantów w przestrzeni publicznej dająca wywieść się z teorii sprawiedliwości libertariańskiego jusnaturalizmu jest reguła syndykalistyczno-komunitarystyczna, która prawo do decydowania o przyjmowaniu imigrantów

Eukasz Dominiak - doktor nauk o polityce w zakresie filozofii polityki, adiunkt w Katedrze Hermeneutyki Polityki WPiSM UMK w Toruniu. 
przyznaje wspólnotom lokalnym oraz pracownikom części sektora publicznego. Metoda badawcza wykorzystana w niniejszych dociekaniach jest metoda analizy logicznej, polegajaca inter alia na analizie pojęciowej, identyfikowaniu i eliminowaniu sprzeczności oraz wywodzeniu relatywnie szczegółowych twierdzeń ze zbioru ogólnych przesłanek oraz aksjomatów przy użyciu logiki werbalnej.

Niniejszy artykuł postępował będzie według następującego porządku: w punkcie 2. zidentyfikowany zostanie zbiór ogólnych przesłanek formalnych przyjmowanych przez libertariański jusnaturalizm, relewantnych dla zagadnienia migracji, oraz przedstawiona zostanie zwięzła analiza języka praw podmiotowych. W punkcie 3. zidentyfikowany zostanie zbiór ogólnych przesłanek substancjalnych przyjmowanych przez libertariański jusnaturalizm, relewantnych $z$ punktu widzenia poruszanego tu zagadnienia migracji, oraz podjęta zostanie krótka dyskusja dwóch wariantów takich zbiorów przesłanek. W punkcie 4. z powyższych przesłanek wywiedziona zostanie odpowiedź libertariańskiego jusnaturalizmu na pierwsze pytanie badawcze. W punkcie 5 . wywiedziona zostanie reguła praktyczna stanowiąca odpowiedź na drugie pytanie badawcze.

Co w tym miejscu musi być już jasne, niniejszy artykuł nie ma charakteru hermeneutycznego czy antykwarycznego, lecz teoretyczny i analityczny. $Z$ tego względu nie będa tu przedstawione ani zinterpretowane poglady tego czy innego libertarianina na problem migracji. Zaproponowany natomiast zostanie szkic teorii politycznej, której wartość nie zależy od tego, jak wiernie wpisuje się ona $\mathrm{w}$ istniejaca ortodoksję libertariańska czy też jak rzetelnie zdaje relację $z$ pogląów obecnych i przyjętych w naszej uczonej literaturze przedmiotu, lecz od tego, jak spójne sa jej argumenty, jak poprawne wnioskowania i jak precyzyjne ostrze analityczne. 


\section{Przesłanki formalne libertariańskiego rozwiązania problemu migracji}

W naukach humanistycznych rzadko ma się do czynienia z praktycznie powszechnym konsensem co do teoretycznego, konceptualnego czy interpretacyjnego ujęcia danego zjawiska, działania czy relacji społecznej. Jednym $z$ wyjątków pod tym względem jest dorobek analitycznej jurysprudencji w zakresie języka uprawnień ${ }^{1}$. Kwestią, która w literaturze przedmiotu nie podlega większej dyskusji, jest twierdzenie, że uprawnienie jednej osoby wiąże się $z$ korelatywnym obowiązkiem spoczywajacym na innej osobie lub osobach. Twierdzenie to uzyskało najbardziej analityczny i precyzyjny wymiar w ramach analizy fundamentalnych pojęć prawnych autorstwa Wesleya Newcomba Hohfelda ${ }^{2}$, która to analiza jest prawie powszechnie uznawanym punktem wyjścia do dalszych badań nad teorią uprawnień ${ }^{3}$. Także libertariański jusnaturalizm czyni swoim punktem wyjścia analizę pojęć prawnych Hohfelda, choć stosuje ją do analizy pojęć prawnonaturalnych ${ }^{4}$. Niniejszy artykuł przyjmuje więc za Hohfeldem następująca aprioryczną matrycę analityczna pojęć prawnych ${ }^{5}$ :

$\begin{array}{cccccc}\text { Prawne } & \text { Osoba A } & \text { uprawnienie } & \text { wolność } & \text { kompetencja } & \text { immunitet } \\ \text { korelaty } & \text { Osoba B } & \text { obowiązek } & \begin{array}{c}\text { brak } \\ \text { uprawnienia }\end{array} & \text { podatność } & \begin{array}{c}\text { brak } \\ \text { kompetencji }\end{array}\end{array}$

$\begin{array}{cccccc}\text { Prawne } & \text { Osoba A } & \text { uprawnienie } & \text { wolność } & \text { kompetencja } & \text { immunitet } \\ \text { przeciwieństwa } & \text { Osoba A } & \text { brak } & \text { obowiazek } & \text { brak } & \text { uprawnienia } \\ \text { niezrobienia } & \text { kompetencji } & \text { podatność }\end{array}$

\footnotetext{
1 J. Narveson, The Libertarian Idea, Broadview Press, Peterborough 2001, s. 41.

2 W.N. Hohfeld, Some Fundamental Legal Conceptions as Applied in Judicial Reasoning, „The Yale Law Journal” 1913, t. 23, nr 1; idem, Fundamental Legal Conceptions as Applied in Judicial Reasoning, „Faculty Scholarship Series” 1917, art. 4378.

3 H. Steiner, An Essay on Rights, Blackwell Publishers, Oxford 1994, s. 59.

4 D.B. Rasmussen, D.J. Den Uyl, Liberty and Nature: An Aristotelian Defense of Liberal Order, Open Court, La Salle 1991, s. 81.

5 Zob. W.N. Hohfeld, Fundamental Legal Conceptions..., s. 710; idem, Some Fundamental..., s. 30 .
} 
Relacje prawne w pierwszych dwóch kolumnach maja charakter relacji pierwszego rzędu, czyli odnoszących się do stanów faktycznych, relacje prawne w dwóch pozostałych kolumnach maja zaś charakter pozycji drugiego rzędu, czyli stosujących się do relacji prawnych pierwszego rzędu ( $z$ pierwszych dwóch kolumn) ${ }^{6}$. Można więc powiedzieć $-z$ pewnymi zastrzeżeniami, które nie sa tutaj przedmiotem zainteresowania - że kompetencja jest wolnościa drugiego rzędu, podatność brakiem uprawnienia drugiego rzędu, immunitet uprawnieniem drugiego rzędu (jest więc uprawnieniem do tego, aby inna osoba nie zmieniła pozycji prawnej osoby chronionej immunitetem), a brak kompetencji obowiąkiem drugiego rzędu.

Dwa najważniejsze $z$ punktu widzenia poruszanego tu problemu pojęcia hohfeldowskie to pojęcie uprawnienia i wolności. Na podstawie powyższej matrycy analitycznej możemy powiedzieć, że przez pojęcie uprawnienia rozumiemy taka relację normatywna, że: osoba $A$ ma uprawnienie, aby osoba $B$ zrobiła $X$ wtedy $i$ tylko wtedy, gdy osoba $B$ ma korelatywny obowiazek zrobienia $X$; oraz osoba A ma uprawnienie, aby osoba $B$ nie zrobiła $X$ wtedy $i$ tylko wtedy, gdy osoba $B$ ma korelatywny obowiazek niezrobienia $X$. Uprawnienie wiąże się więc nierozerwalnie $z$ korelatywnym obowiazkiem o tym samym wektorze spoczywajacym na drugiej stronie (ius in personam) lub stronach (ius in re) relacji normatywnej i jako takie zawsze dotyczy (obowiazkowych) działań innych osób, nigdy zaś działań osoby uprawnionej ${ }^{7}$. Dodatkowo, należy zauważyć, że uprawnienie i skorelowana $z$ nią obowiązkowa natura działań zakłada logicznie możliwość użycia przymusu wobec osób naruszających uprawnienia. Jeśli bowiem osoba A ma uprawnienie, aby osoba $\mathrm{B}$ podjęła działanie $\mathrm{X}$, to podjęcie działania $\mathrm{X}$ przez osobę $\mathrm{B}$ jest ex definitione słuszne czy też uzasadnione. A contrario podjęcie przez osobę $\mathrm{B}$ działania $\mathrm{Y}$, takiego, że $\mathrm{Y}$ uniemożliwia

${ }_{6}$ Por. J. Finnis, Natural Law and Natural Rights, Oxford University Press, New York 2011, s. $199-200$.

7 G. Williams, The Concept of Legal Liberty, „Columbia Law Review” 1956, t. 56, nr 8, s. 1145. 
podjęcie działania $\mathrm{X}$, co symbolizujemy jako $\mathrm{Y}<=>\mathrm{X}$, musi być niesłuszne i nieuzasadnione. Ponownie a contrario podjęcie przez osobę A działania $Z$, takiego, że $Z$ uniemożliwia podjęcie działania $\mathrm{Y}$, co symbolizujemy jako $\mathrm{Z}<=>\mathrm{Y}$, musi być słuszne i uzasadnione. Teraz, jeśli $Z$ polega na użyciu przymusu, użycie przymusu musi być słuszne i uzasadnione. Posługując się hohfeldowskim wokabularzem, można więc powiedzieć, że posiadanie uprawnienia zakłada logicznie posiadanie wolności do jego wyegzekwowania.

$Z$ kolei przez pojęcie wolności rozumiemy taka relację normatywna, że: osoba A ma wolność zrobienia $x$ wtedy $i$ tylko wte$d y$, gdy osoba $B$ ma korelatywny brak uprawnienia, aby osoba A nie zrobiła $x$, czyli wtedy i tylko wtedy, gdy na osobie A nie spoczywa obowiazek niezrobienia $x$; oraz osoba A ma wolność niezrobienia $x$ wtedy i tylko wtedy, gdy osoba $B$ ma korelatywny brak uprawnienia, aby osoba A zrobiła x, czyli wtedy i tylko wtedy, gdy na osobie A nie spoczywa obowiazek zrobienia $x$. Wolność rozumiana jest więc jako brak obowiązku o przeciwnym wektorze i jako taka zawsze dotyczy działań osoby, która ja posiada ${ }^{8}$. Tak rozumiana wolność może być albo naga (naked liberty), albo zabezpieczona ochronnym pasem uprawnień (vested liberty), w którym to przypadku działanie, które mamy wolność podjać, choć samo nie może być przedmiotem naszego uprawnienia (tylko działania innych osób moga być przedmiotem naszego uprawnienia), dzięki byciu zabezpieczonym przez uprawnienia innej treści (na przykład uprawnienia nietykalności osobistej itd.) wygląda tak, jakby było przedmiotem uprawnienia, ponieważ jest prawie równie dobrze chronione przez inne uprawnienia9.

Po wprowadzeniu pojęcia uprawnienia i wolności należy wprowadzić także pojęcie własności. Jusnaturalistyczny libertarianizm rozumie własność zgodnie $z$ tradycja i dorobkiem jurysprudencji jako przede wszystkim prawo do posiadania danej rzeczy będące

8 G. Williams, The Concept of Legal Liberty, s. 1145.

9 H.L.A. Hart, Essays on Bentham: Studies in Jurisprudence and Political Theory, Oxford University Press, New York 2001, s. 171-173. 
$\mathrm{w}$ istocie hohfeldowska zabezpieczoną wolnościa posiadania, $\mathrm{z}$ której wypływaja także inne prawa konstytuujące tę wiązkę relacji normatywnych, która określamy mianem własności ${ }^{10}$. Przez pojęcie posiadania jusnaturalistyczny libertarianizm rozumie zaś stan faktyczny polegający na istnieniu możliwości władania samemu dana rzecza przy wykluczeniu innych osób wraz $z$ intencja takiego władania jak właściciel ${ }^{11}$. Pojęcie posiadania zakłada więc, że dana rzecz może w danym czasie posiadać tylko jedna osoba ${ }^{12}$.

W końcu jasne jest - jak już wzmiankowaliśmy - że libertarianizm nie podejmuje co do zasady problemu praw i uprawnień prawnych (to znaczy pozytywnych lub zwyczajowych), lecz problem praw i uprawnień naturalnych. Przez pojęcie praw naturalnych rozumiemy natomiast - skupiajac się tu jedynie na formalnych warunkach koniecznych - te hohfeldowskie prawa (pozycje prawne), które przysługuja jednostkom $\mathrm{w}$ tak zwanym stanie natury ${ }^{13}$ i które sa racjonalnie uzasadnione ${ }^{14}$. Nie rozstrzygamy przy tym kwestii substancjalnej, które prawa sa racjonalnie uzasadnione, a które nie. Wskazujemy jedynie formalny warunek konieczny, jaki musi spełniać prawo podmiotowe, aby być podmiotowym prawem naturalnym, mianowicie warunek racjonalnego uzasadnienia, czymkolwiek takie uzasadnienie miałoby substancjalnie być.

Formalne pojęcie praw i uprawnień naturalnych jako praw i uprawnień uzasadnionych racjonalnie pozwala nam wydedukować argument przeciwko części substancjalnie dookreślonych systemów praw i uprawnień, które ze względu na relacje logiczne zachodzace pomiędzy ich elementami, nie moga być systemami praw i uprawnień naturalnych. Argument ten przedstawia się

\footnotetext{
${ }^{10}$ Pozostałe prawa własności zob. A.M. Honoré, Ownership, w: A.G. Guest (red.), Oxford Essays in Jurisprudence, Oxford University Press, Oxford 1961, s. 371-375.

${ }^{11}$ F.C. von Savigny, Das Recht des Besitzes: Eine civilistische Abhandlung, Druck und Verlag von Carl Gerold's Sohn, Wien 1865, s. 26.

${ }^{12}$ M. Taylor, Community, Anarchy and Liberty, Cambridge University Press, Cambridge 1995, s. 153.

${ }^{13}$ Przez pojęcie stanu natury rozumiem, ogólnie rzecz biorąc, stan, w którym nie istnieje instytucja państwa.

${ }^{14}$ R. Barnett, The Structure of Liberty, Oxford University Press, New York 2000, s. 16.
} 
następująco. Jeśli przez pojęcie uprawnienia naturalnego rozumiemy takie hohfeldowskie uprawnienie, które jest racjonalnie uzasadnione, to system uprawnień naturalnych także musi być racjonalnie uzasadniony. Jednak nic, co narusza prawo niesprzeczności, nie może być uzasadnione racjonalnie. Stąd system uprawnień, aby mógł być systemem uprawnień naturalnych, nie może być wewnętrznie sprzeczny ani w sensie alternatywy rozłącznej (sprzeczność sensu proprio), ani w sensie dysjunkcji (przeciwieństwo); nie może on więc zawierać w sobie ani sprzecznych, ani przeciwnych sobie uprawnień (i korelatywnych obowiązków). Każdy system uprawnień, który zawiera w sobie sprzeczne lub przeciwne uprawnienia, należy odrzucić jako niebędący systemem uprawnień naturalnych, bez konieczności przeprowadzania badań substancjalnych co do treści tworzących go uprawnień. Ten sam argument stosuje się także do innych niż uprawnienia hohfeldowskich relacji normatywnych, $z$ zastrzeżeniem różnic wynikających $z$ ich specyficznej natury logicznej. Na przykład więc, o ile racjonalnie niemożliwe jest jednoczesne posiadanie i nieposiadanie tego samego uprawnienia czy też posiadanie obowiązku do podjęcia działania $\mathrm{X}$ i posiadanie obowiązu do niepodjęcia działania $\mathrm{X}$, o tyle racjonalnie możliwe jest posiadanie wolności bilateralnej, czyli jednocześnie wolności do podjęcia działania X i wolności do niepodjęcia działania $\mathrm{X}$ - aczkolwiek niemożliwe jest jednoczesne posiadanie i nieposiadanie tej samej wolności itd. System praw, który dopuszczałby na przykład ten ostatni scenariusz, nie mógłby ex definitione być systemem praw naturalnych.

\section{Przesłanki substancjalne libertariańskiego rozwiązania problemu migracji}

W poprzednim podrozdziale określiliśmy sposób, w jaki będziemy posługiwali się pojęciami posiadania, uprawnienia, wolności i własności. Naszą analizę konceptualną można potraktować jako 
dostarczająca zbioru przesłanek formalnych do rozwiąania poruszanego tu zagadnienia. Przesłanki te to hohfeldowska matryca analityczna, pojęcie własności, pojęcie posiadania i formalne warunki konieczne racjonalności systemu praw naturalnych.

Jednak aby móc zaprezentować libertariańskie rozwiąanie problemu migracji, potrzebujemy też kilku (konkretnie dwóch) przesłanek substancjalnych zwiąanych $z$ teoria uprawnień. W paragrafie tym dokonamy ich wprowadzenia. W tym celu zwrócimy się do libertariańskiej teorii sprawiedliwości, która identyfikuje substancjalne zasady dystrybucji praw i uprawnień naturalnych. W pierwszej kolejności zidentyfikujemy zasady sprawiedliwości rzązace transferami dóbr rzadkich, następnie zasady sprawiedliwości rządzące pierwotną dystrybucją dóbr rzadkich.

Każda osoba będąca aktorem moralnym zdolnym do podejmowania aktów woli ma hohfeldowska kompetencję moralną do zobowiązania się aktem woli wobec innej osoby, także będącej aktorem moralnym, do podjęcia działania $\mathrm{X}$ - jeśli jest $\mathrm{w}$ stanie działanie to podjać. Akt takiego zobowiązania najłatwiej wytłumaczyć jako rezygnację $z$ hohfeldowskiej wolności niepodjęcia działania $X$ - brak wolności niepodjęcia działania $X$ jest bowiem tym samym, co obowiazek jego podjęcia - poprzez jej przekazanie osobie, wobec której się zobowiąujemy (można powiedzieć więc, że nasza wolność podjęcia/niepodjęcia danego działania, jeśli znajduje się w dyspozycji innej osoby, jest tej osoby uprawnieniem, abyśmy nie podjęli/podjęli to działanie). Podobnież osoba, wobec której ktoś się zobowiązał, może aktem woli zwolnić go $z$ tego obowiązu, rezygnujac ze swojego korelatywnego uprawnienia, czyli przekazać mu jego wcześniej przetransferowana wolność. Każda osoba będąca aktorem moralnym ma więc kompetencje do rezygnacji ze swojej wolności (a więc do zaciagnięcia zobowiązania) oraz ze swoich uprawnień, a także kompetencję do umorzenia zobowiazania, które inna osoba ma wobec niej. Jasne jest także, że ja sam nie mam kompetencji, aby zwolnić siebie samego ze zobowiazania. Aby bowiem mieć taką kompetencję, musiałbym mieć wolność, 
której brak konstytuuje moje zobowiąanie. Wolność tę ma jednak ktoś inny, ktoś, komu ją wcześniej przekazałem, zaciagając swoje zobowiązanie. Na tej samej zasadzie także nikt inny niż osoba uprawniona nie może zwolnić mnie $z$ mojego korelatywnego obowiazku - tylko bowiem osoba uprawniona „trzyma” moja wolność, której brak konstytuuje mój obowiązek i którą tylko ona może mi oddać ${ }^{15}$.

Osoba A może więc aktem woli (1) zwolnić osobę B z jej zobowiąania, przekazujacc jej swoje uprawnienie, czyli jej wolność; (2) zobowiązać się wobec osoby B, przekazując jej swoją wolność. Osoba A może więc zrobić jednocześnie (1) i (2). Sytuacja taka ma miejsce w przypadku transferu praw własności, konkretnie zaś transferu prawa do posiadania. Osoba A aktem woli (1) zwalnia osobę B $z$ jej zobowiazania do nieingerowania w rzecz X, przekazujac jej swoje uprawnienie do wykluczenia (do nieingerencji ze strony innych) innych osób $z$ władania rzeczą $X$ (w wypadku własności i uprawnienia do wykluczenia innych, które sa prawami in rem, przekazywane uprawnienie jest tak naprawdę wiąka uprawnień erga omnes) oraz (2) zobowiąuje się wobec osoby B do nieingerowania we władanie przez nia rzeczą $X$, przekazując jej tym samym swoja wolność władania rzeczą X. Źródłem praw własności osoby $\mathrm{B}$ do rzeczy $\mathrm{X}$ jest więc akt woli osoby A, aby przekazać osobie B prawa własności do rzeczy $\mathrm{X}^{16}$. Analitycznie rzecz biorąc, prawo własności osoby B do rzeczy X ma więc dwa źródła: zademonstrowany w działaniu akt woli osoby A oraz jej ważny tytuł własności. Gdyby tytuł własności osoby A był nieważny, nie miałaby ona wówczas prawa do posiadania, czyli nie miałaby ani uprawnienia do wykluczenia innych osób $z$ władania rzecza $X$ (uprawnienia do nieingerencji ze strony innych), ani wolności władania rzeczą X, których nie mogłaby w związku $z$ tym przekazać następnie osobie B.

\footnotetext{
${ }^{15}$ H. Steiner, An Essay on Rights, s. 79-85.

${ }^{16}$ Debatę pomiędzy Teorią Woli i Teorią Korzyści w analizie uprawnień zob. M.H. Kramer, N.E. Simmonds, H. Steiner, A Debate Over Rights: Philosophical Enquires, Oxford University Press, New York 2002.
} 
Jej akt woli przekazania praw własności do rzeczy $\mathrm{X}$ byłby więc bezprzedmiotowy i w związku $z$ tym nieskuteczny ${ }^{17}$. Libertariańska zasada sprawiedliwego transferu własności mówi więc, że transfer własności jest sprawiedliwy, jeśli jest dobrowolny i dotyczy ważnych tytułów własności ${ }^{18}$.

To odnosi nas do problemu pierwotnej dystrybucji praw własności. Przy założeniu dobrowolności transferów praw własności, jeśli uzasadnieniem praw własności osoby $B$ do rzeczy $X$ jest to, że prawa te otrzymała od osoby A, poprzedniego właściciela rzeczy $\mathrm{X}$, to tytuł własności osoby $\mathrm{B}$ jest uzasadniony tylko $\mathrm{w}$ tej mierze i do tego stopnia, do jakiego uzasadniony był tytuł osoby A. Ten zaś mógł być uzasadniony tylko do tego stopnia, do jakiego uzasadniony był tytuł własności osoby $Z$, która dokonała jego transferu na rzecz osoby A. $Z$ kolei tytuł osoby $Z$ mógł być uzasadniony tylko do tego stopnia, co tytuł osoby $Y$ itd. Ostatecznie więc tytuł osoby A jest uzasadniony jedynie $\mathrm{w}$ tej mierze, w jakiej uzasadniony był tytuł osoby, która jako pierwsza nabyła prawa własności do rzeczy X - jako pierwsza nie znaczy tu oczywiście jako pierwsza w historii istnienia rzeczy $\mathrm{X}$, ale jako ta, która nabyła prawa własności do rzeczy niczyjej (nawet jeśli kiedyś rzecz ta była już czyjąś własnością, ale następnie stała się niczyja $)^{19}$. Kwestię nabycia pierwotnego tytułu własności do danej rzeczy określa się mianem problemu pierwotnego zawłaszczenia. Aby do pierwotnego zawłaszczenia w ogóle mogło dojść, czyli aby w ogóle mógł ukonstytuować się tytuł własności do danej rzeczy czy też aby dana relacja faktyczna $z$ dana rzecza mogła stać się relacją normatywną. Czynności, które należy podjąć, muszą przebiegać zgodnie $z$ zasadami sprawiedliwości rządzącymi pierwotna dystrybucją dóbr rzadkich. Każda filozofia polityczna stoi przed skomplikowanym zadaniem identyfikacji takich zasad pierwotnej

\footnotetext{
${ }_{17}$ Zob. W.M. Evers, Toward a Reformulation of the Law of Contracts, „Journal of Libertarian Studies" 1977, t. 1, nr 1.

${ }^{18}$ Zob. R. Nozick, Anarchy, State, and Utopia, Blackwell Publishing, Malden 2014, s. 150-153 .

${ }^{19}$ H. Steiner, An Essay on Rights, s. 102-105.
} 
dystrybucji tytułów własności. W ramach libertarianizmu można wskazać dwie dominujące propozycje zasad sprawiedliwości rzadzacych pierwotnym zawłaszczeniem.

Pierwsza propozycja jest laborystyczna teoria własności wywodząca się od Johna Locke'a ${ }^{20}$. Ogólnie rzecz biorąc, mówi ona, że pierwotne tytuły własności powinny być dystrybuowane zgodnie $z$ zasada: każdemu, kto jako pierwszy połaczył swa prace $z$ dana rzecza $w$ celu nabycia własności. Głównym argumentem, który wykonuje tutaj pracę uzasadniajacca, jest twierdzenie, że ponieważ moje ciało należy bezsprzecznie do mnie, to i moja praca - będaca z fizycznego punktu widzenia częścia mojego ciała, tyle że w formie energii $^{21}$ - musi należeć do mnie. Jeśli zaś połączę coś, co należy do mnie, czyli moja pracę, $z$ czymś, co nie należy do nikogo, czyli $z$ niczyja rzecza, to konstytuuje tym samym unikatowy zwiazek pomiędzy mna a tą rzeczą. Unikalność tego związu polega zaś na tym, że odtąd każda kolejna osoba, która chciałaby przeją́ owa rzecz bez mojej zgody, mogłaby tego dokonać, tylko pozbawiajac mnie tego, co słusznie i bezsprzecznie należy do mnie, czyli własności tej części mojej pracy, którą połączyłem $z$ ową rzeczą ${ }^{22}$. Ponieważ, jak zauważyliśmy powyżej, niemożliwy jest niedobrowolny transfer własności - pozycje normatywne sa bowiem konstytuowane tylko i wyłącznie przez działania moralne, konkretnie zaś przez akty woli - to bez mojej zgody żadna inna osoba nie jest w stanie stać się właścicielem rzeczy, która została przeze mnie złączona $z$ moja pracą.

Druga propozycja jest $z$ kolei wywodzaca się $z$ prawa rzymskiego oraz $z$ common law teoria pierwszego posiadania ${ }^{23}$. Ogólnie rzecz biorac, mówi ona, że pierwotne tytuły własności powinny być dystrybuowane zgodnie z zasadą: każdemu, kto jako pierwszy

\footnotetext{
${ }^{20}$ Zob. J. Locke, Dwa traktaty o rzadzie, przekład Z. Rau, Wydawnictwo Naukowe PWN, Warszawa 1992, s. 181-182.

21 H. Steiner, An Essay on Rights, s. 233-234.

${ }^{22}$ E. Mack, John Locke, Continuum International Publishing Group, New York 2009, s. 59.

${ }^{23}$ Zob. R.A. Epstein, Possession as the Root of Title, "Georgia Law Review” 1979, t. 13;

C.M. Rose, Possession as the Origin of Property, "The University of Chicago Law Review" 1985, t. 52 .
} 
wszedł $w$ posiadanie danej rzeczy. Głównym argumentem, który wykonuje tutaj pracę uzasadniajaca, jest natomiast twierdzenie, że rzecz niczyja jest ex definitione taka rzecza, co do której nikt nie zademonstrował w swym działaniu woli objęcia jej wyłączna kontrola fizyczna, a w związku $z$ tym osoba, która jako pierwsza wolę taka demonstruje i która rzecz tę obejmuje taką kontrolą, ex definitione nie wchodzi $\mathrm{w}$ konflikt $z$ żadna inna osobą. $Z$ kolei od momentu wejścia przeze mnie w posiadanie danej rzeczy każda kolejna osoba, która chciałaby wejść w posiadanie tej rzeczy bez mojej zgody, mogłaby tego dokonać, tylko wchodzac ze mna w konflikt. Ponieważ posiadanie jest relacja charakteryzujaca się wyłącznością oraz dotyczy ono zasobów rzadkich, czyli takich, których nie można używać $\mathrm{w}$ tym samym czasie na dwa różne sposoby, to sprzeczność naszych woli musi w tym wypadku oznaczać konflikt, czyli zderzenie fizyczne. Przyjmując, że pomiędzy ludźmi nie istnieje doskonała harmonia celów, jesteśmy w stanie unikać konfliktów wtedy i tylko wtedy, gdy pierwotne tytuły własności dystrybuowane sa $z$ poszanowaniem pierwszego posiadania $^{24}$.

Jasne jest, że dominujące w liberalizmie laborystyczna i posesoryjna zasady dystrybucji pierwotnych tytułów własności nie pokrywaja się ze soba w przewidywaniu, komu przysługuje prawo własności, i są w związku $z$ tym dwiema różnymi zasadami rządzącymi pierwotnym zawłaszczeniem. Można bowiem, po pierwsze, wejść $\mathrm{w}$ posiadanie danej rzeczy bez wchodzenia $z$ nia $\mathrm{w}$ bezpośredni kontakt fizyczny. Wystarczy bowiem, że znajdujemy się w takiej pozycji względem tej rzeczy (która na przykład leży przed nami), że możemy dowolnie manipulować tą rzecza (władać nia) przy wykluczeniu innych osób - nie ma natomiast konieczności, abyśmy nie tylko mogli, ale też aktualnie nią w taki sposób manipulowali

\footnotetext{
${ }^{24}$ Por. inter alia H.H. Hoppe, The Ethics and Economics of Private Property, w: idem, The Great Fiction. Property, Economy, Society, and the Politics of Decline, Laissez Faire Books, Baltimore 2012, s. 15; idem, From Aristocracy to Monarchy to Democracy: A Tale of Moral and Economic Folly and Decay, Ludwig von Mises Institute, Auburn 2014, s. 19-21; idem, A Theory of Socialism and Capitalism, Ludwig von Mises Institute, Auburn 2012, s. 19.
} 
(władali) ${ }^{25}$. Po drugie, możemy połączyć dany zasób z naszą praca, nie wchodzac jednak $\mathrm{w}$ jego posiadanie, jak ma to miejsce inter alia w przypadku pogoni za zwierzętami feroe naturoe ${ }^{26}$. W związku $z$ tym, że zasady te rodzą więc sprzeczne rozstrzygnięcia co do dystrybucji tytułów własności, tylko jedna $z$ nich może ostatecznie rządzić taka dystrybucją. Choć artykuł ten nie jest miejscem do rozstrzygnięcia kwestii supremacji jednej $z$ tych zasad - i w obszarze poruszanego tu zagadnienia migracji obie te zasady wydaja się prowadzić do takich samych rozwiązan - to wskazać należy, iż wydaje się, że zasada laborystyczna, która jako przesłankę przyjmuje prawa autowłasności i sama nie jest w zwiąku $z$ tym zdolna do ich uzasadnienia czy wyjaśnienia (zakłada bowiem ich ważność jako swoje Bedingungen der Möglichkeit), musi więc presuponować istnienie jakiejś bardziej fundamentalnej niż ona sama zasady dystrybucji pierwotnych praw własności (zwłaszcza pierwotnych praw autowłasności). Zasada tą wydaje się zasada pierwszego posiadania $^{27}$, której ważność przyjmuje także niniejszy artykuł.

Libertariańska teoria sprawiedliwości identyfikuje więc następujace substancjalne zasady dystrybucji uprawnien naturalnych: (1) w obszarze pierwotnej dystrybucji tytułów własności zasadę pierwszego posiadania; (2) w obszarze wtórnej dystrybucji tytułów własności, nabytych zgodnie $z$ pierwszą zasada, zasadę dobrowolnego transferu. Wszystkie hohfeldowskie prawa własności - ze szczególnym miejscem prawa do posiadania, z którego wypływają wszystkie inne relacje normatywne konstytuujące prawa własności - nabyte zgodnie $z$ zasadami pierwszego posiadania (przekształcenie rzeczy w drodze produkcji jest wariantem pierwotnego nabycia) i dobrowolnego transferu oraz uściślajacymi je zasadami niższego rzędu (jak konsensualna teoria umów ${ }^{28}$ itd.) konstytuują system naturalnych praw własności prywatnej.

\footnotetext{
${ }^{25}$ W.A. Hunter, Roman Law In the Order of a Code, William Maxwell \& Son, London 1885, s. 343 .

${ }^{26}$ Pierson vs. Post, 3 Caines 175 (N.Y. 1805), 2 Am. Dec. 264 (N.Y. 1886).

27 R.A. Epstein, Possession..., s. 1227.

${ }^{28}$ Zob. R. Barnett, A Consent Theory of Contract, „Columbia Law Review” 1986, t. 86, nr 2.
} 
$Z$ kolei wszystkie tytuły prawne - ex definitione niebędace prawami czy uprawnieniami naturalnymi - powstałe w drodze naruszenia zasad pierwszego posiadania i dobrowolnego transferu konstytuuja natomiast prawa własności publicznej.

\section{Problem niemożliwości istnienia uprawnienia do migracji}

Mając już określony pełen zbiór przesłanek formalnych i substancjalnych, w tym podstawową siatkę pojęciowa, jesteśmy w stanie przejść do rozwiązania stawianych tu problemów badawczych. W pierwszej kolejności zajmiemy się odpowiedzia na pytanie, dlaczego $z$ libertariańskiej teorii sprawiedliwości nie można wywieść uprawnienia do migracji.

Rozważania nasze należy rozpoczać od zwrócenia uwagi na rudymentarna cechę charakterystyczna libertariańskiego ładu politycznego, mianowicie na fakt, że w porządku tym nie występuje własność publiczna, czyli własność powstała w wyniku naruszenia naturalnych praw własności prywatnej - ład libertariański jest antyteza ładu publicznego. Oznacza to, że w libertariańskim społeczeństwie prawa prywatnego nie może istnieć instytucja państwa, a w związku $z$ tym nie moga także istnieć granice pomiędzy państwami. Dlatego migracja rozumiana jako przekraczanie granic państwowych traci $\mathrm{w}$ porządku prawa prywatnego raison d'être. Przemieszczanie się ludności w społeczeństwie libertariańskim może więc dokonywać się jedynie pomiędzy prywatnymi domenami należacymi do poszczególnych właścicieli. Przez pojęcie migracji w ładzie libertariańskim rozumie się zatem przemieszczanie się ludności pomiędzy prywatnymi domenami, tak że opuszczenie własnej domeny oznacza emigrację, przybycie na cudza domenę zaś oznacza imigrację ${ }^{29}$. $Z$ tego względu nasz pierwszy problem badawczy

\footnotetext{
${ }^{29}$ Pojęcie migracji w społeczeństwie libertariańskim jest w niniejszym artykule zrekonstruowane teoretycznie jako przemieszczanie się pomiędzy domenami należącymi do różnych
} 
należy uściślić, jak następuje: dlaczego $z$ libertariańskiej teorii sprawiedliwości nie można wywieść uprawnienia do przemieszczania się pomiędzy prywatnymi domenami należącymi do różnych właścicieli?

Jak wynika $z$ pojęcia uprawnienia, zawsze dotyczy ono działań innych osób niż uprawniony i wiąże się $z$ istnieniem po ich stronie korelatywnego obowiązku. Jeśli więc osoba A miałaby uprawnienie do migracji, znaczyłoby to, że na osobach $\mathrm{B}, \mathrm{C}, \mathrm{D}$ itd. spoczywałyby korelatywne obowiazki niepowstrzymywania osoby A od wkroczenia i pozostawania w miejscu (nazwijmy je miejscem X), do którego osoba A miałaby wolę się udać. Jeśli jednak miejsce $\mathrm{X}$ jest własnościa osoby $B$, to, jak wynika $z$ pojęcia własności, osoba $\mathrm{B}$ ma między innymi prawo do posiadania miejsca $\mathrm{X}$, czyli wolność do wyłącznego władania miejscem $\mathrm{X}$ i uprawnienie do wykluczenia $z$ niego każdej innej osoby (uprawnienie do nieingerencji ze strony innych), w tym osoby A. Jak zauważyliśmy powyżej, pojęcie uprawnienia zakłada $z$ kolei wolność do wyegzekwowania od osoby zobowiazanej obowiazkowego działania. Osoba B, majac więc uprawnienie do wykluczenia osoby A $z$ terenu $X$ (uprawnienie do nieingerencji ze strony A), ma również zabezpieczona wolność do jego wyegzekwowania, czyli do powstrzymania osoby A od ingerencji, a więc od wkroczenia i pozostawania $\mathrm{w}$ miejscu $\mathrm{X}$. Gdyby jednak osoba A mogła mieć uprawnienie do migracji, znaczyłoby to, że na osobie B spoczywałby korelatywny obowiązek niepowstrzymywania osoby A od wkroczenia i pozostawania

\footnotetext{
właścicieli. Decyzja ta uzasadniona jest identyfikacja przypadku przemieszczania się pomiędzy domenami należącymi do tego samego właściciela, lecz oddzielonymi od siebie innymi domenami jako problemu badawczego przynależnego raczej analizie konceptualnej naturalnych praw własności niż ich aplikacji do konkretnych zagadnień praktycznych, jakimi sa między innymi kwestie dotyczace migracji. Przypadek przemieszczania się pomiędzy własnymi domenami dotyczy więc przede wszystkim pytania o to, czy właściciele innych domen maja prawo skutecznie odmówić przejazdu przez ich domeny osobie, która porusza się pomiędzy swoimi domenami. Problem ten wymaga oddzielnego studium i rozważamy go w innym artykule (The Blockian Provisio and Rationality of Property Rights, w przygotowaniu). W tym miejscu możemy jedynie pozwolić sobie na wskazanie, że nie mają oni takiego prawa, a więc że $z$ prawnonaturalnego punktu widzenia nie ma różnicy pomiędzy przemieszczaniem się pomiędzy swoimi domenami rozdzielonymi własnością innych osób a przemieszczaniem się wewnątrz swojej domeny.
} 
w miejscu X. Jednak, jak wskazaliśmy powyżej, obowiazek jest tym samym, co brak wolności o przeciwnym wektorze, czyli obowiązek niepowstrzymywania oznacza to samo, co brak wolności do powstrzymywania. Gdyby więc osoba A miała uprawnienie do migracji, wówczas osoba B jednocześnie miałaby wolność do powstrzymania osoby A od wkroczenia i pozostawania w miejscu $\mathrm{X}$ oraz nie miałaby wolności do powstrzymania osoby A od wkroczenia i pozostawania w miejscu X. Sytuacja ta reprezentuje oczywiście sprzeczność logiczna sensu stricto i nie może mieć miejsca w systemie naturalnych praw własności.

Należy przy tym dodatkowo zauważyć, że sprzeczność, która tutaj zachodzi, jest tego rodzaju, iż działa na niekorzyść jedynie uprawnienia do migracji, nie zaś na niekorzyść naturalnych praw własności prywatnej - jak ktoś mógłby starać się twierdzić na podstawie na pierwszy rzut oka słusznej obserwacji, iż sam fakt sprzeczności pomiędzy dwoma sądami nie wydaje się jeszcze rozstrzygać, który $z$ dwóch sprzecznych sądów należy odrzucić. Istnienie uprawnień do migracji zakłada bowiem jako swój warunek konieczny istnienie praw do posiadania ciał, które owej migracji dokonuja, czyli praw autowłasności. Bez praw autowłasności nie mogłyby istnieć uprawnienia do migracji. Natomiast prawa autowłasności moga istnieć bez uprawnień do migracji. Sugestia, jakoby fakt sprzeczności pomiędzy uprawnieniami do migracji i prawami autowłasności oraz wynikajacymi $z$ nich innymi naturalnymi prawami własności prywatnej pozwalał na zachowanie tych pierwszych kosztem odrzucenia tych drugich, nie jest logicznie rzecz biorac do przyjęcia. Odrzucenie naturalnych praw własności prywatnej, zwłaszcza praw autowłasności, które sa warunkiem koniecznym istnienia uprawnień do migracji, musi oznaczać jednoczesne odrzucenie uprawnień do migracji, ale nie vice versa.

Poza powyższym stricte logiczno-konceptualnym argumentem przeciw możliwości istnienia uprawnienia do migracji w ładzie libertariańskim można wskazać także argument substancjalny. Jak wynika $z$ libertariańskiej teorii sprawiedliwości, prawa włas- 
ności do danej lokacji X można nabyć tylko na dwa sposoby: albo $\mathrm{w}$ wyniku pierwotnego zawłaszczenia $\mathrm{w}$ drodze wejścia w pierwsze posiadanie lokacji $\mathrm{X}$, albo w wyniku dobrowolnego transferu praw własności do lokacji X od jej poprzedniego prawowitego właściciela do jej nowego właściciela (lub do osoby, której tytuł $-z$ uwagi na transfer warunkowy lub dotyczący tylko części praw własności - jest mniej niż własność, exempli gratia komodatariusza, uzufruktuariusza itd.). Przyznanie osobie A uprawnienia do migracji do należącej do osoby $\mathrm{B}$ lokacji $\mathrm{X}$ oznaczałoby przyznanie osobie A uprawnienia do wykluczenia innych osób, w tym osoby B, $z$ lokacji X, na która migrowałaby osoba A. Uprawnienie do wykluczenia innych osób $z$ lokacji $X$ jest zaś kluczowym elementem praw własności do lokacji X. Owo prawo własności do lokacji X zostałoby więc nabyte przez osobę A w innej drodze niż pierwotne zawłaszczenie czy dobrowolny transfer od osoby B. Nie może więc być ono wywiedzione $z$ libertariańskiej teorii sprawiedliwości.

Co więcej, powyższy argument substancjalny wskazuje także, dlaczego uprawnienie takie nie mogłoby być uzasadnione na gruncie libertarianizmu nawet $\mathrm{w}$ szczególnym przypadku migracji na res nullius. Uprawnienie do migracji oznaczałoby tu bowiem pierwotne nabycie jednego $z$ praw własności w inny sposób niż poprzez wejście w pierwotne posiadanie res nullius. Bez względu więc na skomplikowane pytanie o to, w jaki sposób możliwe byłoby dotarcie do ziemi niczyjej, a także czy oraz na jakich warunkach możliwe byłoby istnienie res nullius w społeczeństwie prawa prywatnego, przyznanie uprawnienia do migracji na ziemię niczyja nie jest możliwe na gruncie libertariańskiej teorii sprawiedliwości.

Widać więc, że zarówno $z$ punktu widzenia analizy konceptualnej naturalnych praw własności, zwłaszcza hohfeldowskich uprawnień i wolności, jak i z perspektywy substancjalnej teorii sprawiedliwości libertariańskiego jusnaturalizmu uprawnienie do migracji jako sprzeczne $z$ prawami własności prywatnej oraz rządzącymi ich dystrybucją zasadami sprawiedliwości nie jest możliwe w społeczeństwie prawa prywatnego. Jest tak bez względu na to, $z$ jakiego 
rodzaju migracja mamy do czynienia - czy to pomiędzy prywatnymi domenami, czy pomiędzy domena prywatna a res nullius. Niemożliwość, $z$ która mamy tutaj do czynienia, jest przede wszystkim niemożliwością logiczną. Posługując się teorią możliwych światów Leibniza, można zauważyć, że uprawnienia do migracji oraz prawa własności prywatnej nie sa tego typu relacjami logicznymi, które moga współwystępować $\mathrm{w}$ ramach tego samego możliwego uniwersum prawnego. Dodatkowo niemożliwość ta jest także natury normatywnej. Libertariańskie zasady sprawiedliwości wykluczaja istnienie uprawnień do migracji, identyfikujac je tym samym jako niesłuszne roszczenia, działania zaś podejmowane na ich podstawie jako naruszające uprawnienia innych osób.

\section{Reguły praktyczne rządzące migracja w przestrzeni publicznej}

Rozwiązawszy pierwszy problem badawczy, możemy przejść do naszego drugiego pytania: jaka regułę praktyczna decydowania o przyjmowaniu imigrantów w przestrzeni publicznej można wywieść $z$ libertariańskiej teorii sprawiedliwości? Problem ten można także sformułować jako pytanie o to, jaka polityka migracyjna byłaby uzasadniona $z$ punktu widzenia libertarianizmu, jeśli miałaby być realizowana nie $\mathrm{w}$ inteligibilnym porzadku prawa prywatnego, lecz $\mathrm{w}$ obecnie istniejacych społeczeństwach zachodnich. Aby odpowiedzieć na to pytanie, należy dokonać analizy statusu prawnonaturalnego osób tworzących i korzystających z własności publicznej.

Nasza analizę rozpoczniemy od przypomnienia przywołanej powyżej definicji własności publicznej. Przez pojęcie własności publicznej rozumiemy własność uznana przez empirycznie istniejacy system prawa pozytywnego lub zwyczajowego, która powstała w wyniku naruszenia naturalnych praw własności prywatnej. Ze względu na stosunek do tak rozumianej własności publicznej możemy analitycznie wyróżnić trzy rodzaje statusów prawno- 
naturalnych, które mogą przysługiwać poszczególnym jednostkom. Po pierwsze, status poszkodowanego, czyli osoby, której naturalne prawa własności prywatnej zostały naruszone. Po drugie, status sprawcy, czyli osoby, która dokonała naruszenia naturalnych praw własności prywatnej. Po trzecie, status pasera, czyli osoby, która w jakikolwiek sposób posługuje się skradziona przez kogoś innego rzecza $^{30}$. Dysponujac tym aparatem pojęciowym, jesteśmy w stanie odpowiedzieć na nasze drugie pytanie badawcze.

Przede wszystkim w sytuacjach, w których jesteśmy w stanie przypisać jednoznacznie konkretne statusy prawnonaturalne konkretnym osobom w odniesieniu do konkretnej lokacji, która stała się własnościa publiczna, jasne jest, że wynikająca $z$ libertariańskiej teorii sprawiedliwości reguła praktyczna decydowania o przyjmowaniu imigrantów na tej lokacji mówiłaby, że decyzje takie ma prawo podjąć jedynie poszkodowany. Jednocześnie zarówno tytuł własności, jak i faktyczne posiadanie tej lokacji powinno natychmiast wrócić do poszkodowanego bez odszkodowania dla pasera - wprost przeciwnie, $z$ odszkodowaniem od pasera dla poszkodowanego za wszystkie dodatkowo poniesione straty i nieosiagnięte korzyści, w tym za te związane $z$ wcześniejsza niemożliwościa podejmowania decyzji o przyjęciu lub nieprzyjęciu imigrantów. Paser $z$ kolei mógłby wnosić o odszkodowanie za swoje straty (w tym straty wynikłe $z$ roszczeń poszkodowanego) od sprawcy ${ }^{31}$.

Problem pojawia się jednak w sytuacji, w której nie jesteśmy w stanie przypisać jednoznacznie konkretnych statusów prawnonaturalnych konkretnym osobom w odniesieniu do konkretnej lokacji, która stała się własnością publiczną. Może tak być $z$ wielu

\footnotetext{
${ }^{30}$ Oczywiście nie posługujemy się tutaj pojęciami kradzieży i paserstwa $\mathrm{w}$ technicznym, prawnokarnym sensie. Przez pojęcie kradzieży rozumiemy każdy rodzaj naruszenia naturalnych praw własności prywatnej, to jest na osobie, na mieniu ruchomym, nieruchomym itd. Przez pojęcie paserstwa $z$ kolei rozumiemy wszelkie posługiwanie się, to jest używanie, posiadanie, dzierżenie, czerpanie dochodów i pożytków itd. $z$ rzeczy uzyskanej w wyniku tak rozumianej kradzieży dokonanej przez inną osobę. Przez pojęcie rzeczy rozumiemy zaś wszelki czasowo-przestrzenny komponent działania ludzkiego.

${ }^{31}$ Zob. M. Rothbard, The Ethics of Liberty, New York University Press, New York 1998, s. $57-61$.
} 
powodów, na przykład kradzież może być dokonywana w drodze opodatkowania dochodów, inflacji czy prawnych regulacji działań jednostek, $z$ których to wpływów tworzona jest następnie lokacja, do której dokonuje się migracja ${ }^{32}$. W takiej sytuacji trudno jest jednoznacznie zidentyfikować poszkodowanych i paserów - jakkolwiek relatywnie łatwo jest wskazać sprawców, czyli tych, którzy uczestnicza $\mathrm{w}$ procesie uchwalania i egzekwowania podatków czy regulacji na każdym szczeblu tego procesu. W przypadku niemożliwości identyfikacji poszkodowanych, czyli prawowitych właścicieli danej lokacji i odróżnienia ich od paserów, jesteśmy zmuszeni postępować $\mathrm{w}$ tym zakresie tak, jak gdyby prawowity tytuł własności wygasł i dana lokacja stała się res nullius - ziemią ponownie podatna na pierwotne zawłaszczenie. W tym wypadku prawo do decydowania o przyjęciu imigrantów na takiej lokacji miałaby osoba lub osoby, które dokonałyby jej pierwotnego zawłaszczenia $\mathrm{w}$ drodze wejścia $\mathrm{w}$ pierwsze posiadanie. Osoby te mogłyby się rekrutować zarówno $z$ grupy poszkodowanych, jak i paserów, gdyż choć $z$ moralnego punktu widzenia różne, to $z$ perspektywy reguly praktycznej grupy te nie sa od siebie odróżnialne $\mathrm{w}$ ramach analizowanego tu scenariusza. $Z$ kolei jasne jest, że takiego pierwotnego zawłaszczenia nie mogliby dokonywać sprawcy, ponieważ bez względu na poziom wyrafinowania w sztuce ukrywania łupu sprawca kradzieży, czyli niedobrowolnego transferu danej rzeczy od jej właściciela do siebie, ex definitione nie może się znaleźć w pozycji osoby, do której nastapił dobrowolny transfer tej samej rzeczy, pod tym samym względem i w tym samym czasie - a jak zauważyliśmy powyżej, transfer praw własności może nastapić tylko dobrowolnie. Zatem pomimo że nie jesteśmy w stanie zidentyfikować prawowitych właścicieli i odróżnić ich od paserów

\footnotetext{
${ }^{32}$ Jak już zauważyliśmy powyżej, przez pojęcie kradzieży w szerokim sensie tego słowa libertarianizm rozumie każdy niedobrowolny transfer własności lub posiadania, w tym dokonany w wyniku oszustwa czy fałszerstwa. Status prawno-pozytywny takiego transferu nie ma w tym wypadku znaczenia. Na przykład więc inflacja jest jedynie szczególnym przypadkiem kradzieży polegającym na produkcji pieniądza bez pokrycia w towarze (fałszerstwo) i użyciu go do nabycia dóbr i usług, tak jakby był on prawdziwym pieniądzem (oszustwo).
} 
- i $\mathrm{z}$ tego powodu musimy $\mathrm{w}$ tym zakresie postępować tak, jak gdyby prawowity tytuł własności wygasł - to $z$ pewnościa możemy zidentyfikować tych, którzy nie maja tytułu własności do środków tworzacych publiczna lokację i którzy w związku $z$ tym nie moga dokonać jej pierwotnego zawłaszczenia.

Znając już ogólną regułę praktyczną rządząca decydowaniem o przyjmowaniu imigrantów w tak zwanej przestrzeni publicznej, należy jeszcze dokonać jej uszczegółowienia w związu z praktyka kontrolowania publicznych lokacji. Jeśli weźmiemy jakieś typowe miejsce publiczne: park miejski, droge prowadzaca przez dane osiedle, szkołę, uniwersytet, szpital, państwowa fabrykę itd., zauważymy, że praktycznie nigdy miejsce takie nie jest kontrolowane przez jedna osobe (w tym wypadku rekrutująca się $z$ grupy poszkodowanych lub paserów, ponieważ sprawcy nie maja możliwości pierwotnego zawłaszczenia publicznej lokacji). Praktycznie zawsze kontrola ta przynależy wielu osobom $z$ danej wspólnoty lokalnej, kondominium czy załogi pracowniczej. W sposób zupełnie naturalny to właśnie członkowie tych wspólnot dokonaliby pierwotnego zawłaszczenia - na zasadzie wydzielenia $z$ danej lokacji indywidualnych sublokacji, które stałyby się własnością prywatną konkretnych jednostek, zawłaszczenia indywidualnych udziałów w całości lokacji czy też na zasadzie współwłasności itd. - lokacji publicznych, gdyby przerwane zostały naruszenia ich praw naturalnych dokonywane przez sprawców. Można by nawet próbować argumentować, że wspólnoty te już dokonały takiego zawłaszczenia - pomimo trwajacych naruszeń - wchodzac w faktyczne posiadanie tych lokacji czy też łącząc je ze swoja praca, ponieważ w sytuacji wykluczenia możliwości nabycia tytułów własności do tych lokacji przez sprawców to właśnie te wspólnoty maja najsilniejszy, de facto jedyny, tytuł do tych miejsc.

Stąd rozwiązaniem praktycznym, które wynika $z$ libertariańskiej teorii sprawiedliwości i jej aplikacji do obecnych realiów, jest reguła komunitarystyczno-syndykalistyczna, która stanowi, że prawo do podejmowania decyzji co do własności publicznej maja 
małe wspólnoty lokalne i pracownicy państwowych zakładów pracy na co dzień korzystający $z$ tych lokacji, a więc mieszkańcy konkretnych osiedli, kondominiów, pracownicy konkretnych publicznych szkól, uniwersytetów, szpitali czy fabryk, którzy jako jedyni moga wylegitymować się naturalnym tytułem do tych zasobów ${ }^{33}$. $Z$ tego względu tylko małe wspólnoty lokalne maja prawo podejmowania decyzji co do przyjęcia imigrantów na naturalnie należących do nich placach, drogach, parkach czy budynkach użyteczności publicznej ${ }^{34}$. Wszelkie decyzje polityczne podejmowane na szczeblu wyższym niż mała wspólnota lokalna nie są $z$ punktu widzenia libertarianizmu możliwe do uzasadnienia ani na poziomie koniecznej reguły praktycznej, ani tym bardziej na poziomie uniwersalnych zasad sprawiedliwości i maja charakter naruszajacej naturalne prawa jednostek i wspólnot uzurpacji.

\section{Podsumowanie}

W artykule tym wskazaliśmy, że: 1 . teoria sprawiedliwości libertariańskiego jusnaturalizmu nie może i nie uzasadnia istnienia uprawnienia do migracji - zarówno $z$ powodów formalnych, jak i substancjalnych; 2. reguła praktyczna rzadzaca procesem decyzyjnym w sprawie przyjmowania imigrantów w przestrzeni publicznej dająca wywieść się $z$ teorii sprawiedliwości libertariańskiego jusnaturalizmu jest reguła komunitarystyczno-syndykalistyczna, która prawo do decydowania o przyjmowaniu imigrantów na danych lokacjach przyznaje małym wspólnotom lokalnym oraz pracownikom części sektora publicznego.

\footnotetext{
${ }^{33}$ Zob. H.H. Hoppe, Democracy: The God That Failed. The Economics and Politics of Monarchy, Democracy, and Natural Order, Transaction Publishers, New Brunswick 2007, s. 121-136.

${ }^{34}$ Należących do nich oczywiście na zasadzie naturalnej własności bądź współwłasności z punktu widzenia libertariańskiej teorii sprawiedliwości. Z punktu widzenia obecnego porządku prawno-pozytywnego lokacje te stanowia własność państwa.
} 